\title{
Zinc supplementation during pregnancy: a double blind randomised controlled trial
}

\author{
Kassam Mahomed, David K James, Jean Golding, Rosie McCabe
}

\begin{abstract}
Objective-To see whether zinc supplementation during pregnancy improves maternal and fetal outcome.

Design-Prospective study started at booking and continued till discharge of mother and baby from the maternity hospital. Mothers were randomly assigned to receive zinc supplementation or placebo in a double blind trial.

Setting-Mothers booking at one hospital.

Patients-Women booking before 20 weeks of gestation who agreed to take part in the study. 494 Mothers were followed up till the end of pregnancy. There was no difference between the groups given zinc and placebo in their social or medical backgrounds.
\end{abstract}

Interventions-Mothers in the active treatment group received one capsule of $20 \mathrm{mg}$ elemental zinc daily and those in the placebo treated group a capsule identical in appearance and taste with the active capsule but which contained inert substances.

Main outcome measure-Various adverse outcomes were tested, including maternal bleeding, hypertension, complications of labour and delivery, gestational age, Apgar scores, and neonatal abnormalities. The main outcome measure was birth weight.

Results-There were no differences whatsoever between mothers given a zinc supplement and those given a placebo.

Conclusion-Zinc supplementation in pregnancy in the United Kingdom does not seem to offer any benefits to the mother or her fetus.

\section{Introduction}

Zinc is an essential trace element in many metabolic pathways. ${ }^{\prime}$ Frank zinc deficiency induced in laboratory animals is associated with reduced fertility, ' fetal neurological malformations, and growth retardation in late pregnancy. ${ }^{3}$ In human pregnancies, however, the picture is more complex. Pregnancies occurring in women with acrodermatitis enteropathica are subject to congenital malformations and increased losses. ${ }^{+}$In otherwise normal women low maternal plasma or serum zinc concentrations have been reported to be associated with abnormalities of labour, atonic bleeding, congenital malformations,, preterm labour, ${ }^{5}$ and post-term pregnancies. There are also reports of low plasma zinc values in women who developed hypertension in pregnancy. " Prema ${ }^{1 / \prime}$ and Ghosh et al," however, were unable to predict any abnormal outcome of pregnancy on the basis of serum zinc concentrations.

The relation between maternal zinc concentrations and birth weight is also inconsistent. Prasad et al ${ }^{12}$ and Atinmo $e t a l^{13}$ found a positive correlation but this was not confirmed by others, ${ }^{1+16}$ and several workers have even noted an inverse relation between fetal size and maternal plasma zinc value. . $^{x-101}$

These inconsistent findings may be related to the insensitivity of plasma zinc as an indicator of zinc state. ${ }^{18}$ Jones et al found a close correlation between concentrations of zinc in leucocytes and muscle ${ }^{14}$ but not between plasma zinc and either muscle zinc or leucocyte zinc concentrations ${ }^{21}$; as skeletal muscle contains a large proportion of body zinc, they suggested that the leucocyte zinc concentration might be the more useful indicator of tissue state. A direct correlation has been found between fetal growth retardation and maternal leucocyte zinc concentration ${ }^{1621.2}$ but not maternal plasma zinc value. ${ }^{21}$ Simmer and Thompson showed a relation between intrauterine growth retardation and postnatal polymorphonuclear leucocyte zinc concentration as a measure of zinc state..$^{23}$

The suggested associations between maternal zinc depletion and poor outcome of pregnancy raise the possibility of prevention by using supplementary zinc. The efficacy of such a strategy has yet to be fully assessed. This study therefore aimed at assessing the value of zinc supplementation during pregnancy on the outcome of pregnancy in a pregnant population in Bristol.

\section{Patients and methods}

Women booking for delivery at Southmead Hospital, Bristol, were eligible for entry if they were less than 20 weeks pregnant at the first visit. Enrolment took place between September 1985 and March 1986. An ultrasound scan was done in $95 \%$ of cases, and if gestation differed by more than one week from that calculated from the date of the last menstrual period we accepted the calculation based on the ultrasonic image. At the end of the visit potential volunteers were seen by the research midwife, who explained the study fully. Written information and an instruction sheet were also given to the volunteers, who then gave written consent to participate. The study was approved by the district research and ethical committee.

Sample size was calculated on the basis of an earlier study from this unit ${ }^{22}$ which indicated that a $50 \%$ reduction in growth retardation might be expected with zinc supplementation. A population of 500 mothers would give an $80 \%$ chance of detecting such a reduction at the $5 \%$ level of significance.

Volunteers were then randomly allocated to receive a capsule containing $20 \mathrm{mg}$ elemental zinc $(66 \mathrm{mg}$ zinc sulphate) or a capsule containing inert substances (sucrose, maize starch, purified talc, kaolin, gelatin) but which was indistinguishable in appearance and taste from the one containing zinc. The capsules were prepared by Smith Kline and French Ltd. Neither the investigators nor the mothers knew the content of the capsules, and the code was not broken until the completion of the study. Allocation to the capsules was performed in successive groups of five mothers by means of a computer generated randomisation schedule.

The mothers were advised to take one capsule daily after breakfast. Serum haemoglobin and ferritin concentrations were measured in all women at the first visit. Iron and folate supplementation was advised only if the haemoglobin concentration was less than $100 \mathrm{~g} / \mathrm{l}$ or the serum ferritin concentration was less than $10 \mu \mathrm{g} / \mathrm{l}$. 
An information sheet was posted to the mother's general practitioner explaining the study as well as the need to avoid giving routine iron and folate supplementation. General practitioners, however, were free to give supplements if that was their routine practice. If supplements were prescribed patients were advised to take the iron and folate tablet in the evening and to avoid taking the iron and study capsules together.

Enough capsules were provided to last till the next hospital visit. The mothers were seen by the research midwife at the 28-32 week visit and again on the day after delivery. At each visit information was obtained about the use of any other drugs or iron or vitamin supplementation. Compliance was assessed by the regularity with which the study capsules were taken. Those who took the supplement daily or on most days were grouped as compliers, and the rest were regarded as non-compliers.

At the 28-32 week visit the mothers were asked to complete a seven day dietary diary. The diary was carefully explained to each mother and she was asked to start the diary by describing all she had eaten or drunk on the day of the interview. The interviewer then went through this item by item, ensuring a full description with estimates of quantity. Mothers returned the diaries at the end of seven days. Coders then coded the quantity and the item consumed. A computer dictionary was created for each item, giving the various constituents, based on McCance and Widdowson's tables ${ }^{24}$ as updated by the Medical Research Council's study of health and development. ${ }^{2}$ A special effort was made to ensure accurate values for zinc. This included different values for drinking water based on the area of the city in which the mothers lived.

During the study and after delivery clinical details were recorded by the research midwife by interview as well as from the case records. Several categories of adverse outcomes in pregnancy were compared, chosen from published reports and theoretical considerations (see appendix). The main effect considered was birth weight. Information on outcome was coded by a person who did not participate in the clinical care of the woman, and the data were analysed with the statistical package for the social sciences (SPSS-X) and the biomedical programs data package. Comparison of frequencies was by the $\gamma^{2}$ test with Yates's correction where appropriate. When numbers were very small Fisher's exact test was employed. $t$ Tests were used to compare means and the Mann-Whitney $U$ test to compare median values. Statistical significance was taken at the $5 \%$ level. Though the study was designed to look at beneficial effects, we were also keen to examine adverse outcomes, so two tailed tests were used. Confidence intervals may be calculated from the data given.

\section{Results}

A total of 500 women were successfully enrolled, by chance 250 in each group. Of these, four moved out of the area and two miscarried immediately after enrolment. The remaining 494 women (246 given zinc supplementation, 248 given placebo) were therefore available for study. There were no significant differences between the zinc supplementation and placebo treated mothers in their social and biological backgrounds. They were of similar ages and had similar obstetric histories (table I). At the time of enrolment (at booking) there were no differences in maternal weights, blood pressure measurements, or haemoglobin, ferritin, or leucocyte zinc concentrations. The proportion of mothers who were smoking was similar, as was the prevalence of a history of nausea or vomiting and of urinary infection.

At the subsequent visit (between 28 and 32 weeks' gestation) there were no significant differences between the two groups of mothers. There was a suggestion, however, that the mothers receiving the zinc supplement had lower zinc concentrations $(p=0 \cdot 06)$ than the controls (table II).

Of the 494 mothers, 375 (76\%) completed a seven day dietary diary, 347 giving details for the whole seven days. There was no difference in nutrient intake between the groups (table III). In particular, there was no difference in mean zinc intake, which was only half the recommended intake $(20 \mathrm{mg})$ for pregnant mothers. Dietary items known to reduce the absorption of zinc, such as alcohol, iron, total fibre (and cereal fibre), were consumed in equal amounts in the two groups.

By the time the mothers were delivered similar numbers had taken iron supplements, and among women who had taken these supplements similar proportions claimed to have taken the iron at a different time of day from the zinc ( 83 of 93 women given the active supplement, 65 of 82 given placebo; NS).

TABLE I-Maternal characteristics at booking in the two groups. Except where stated otherwise figures are numbers (percentages) of mothers

\begin{tabular}{|c|c|c|c|}
\hline \multicolumn{2}{|c|}{ Characteristic } & $\begin{array}{l}\text { Zinc supplementation } \\
\text { group }(\mathrm{n}=246)\end{array}$ & $\begin{array}{c}\text { Placebo } \\
\text { supplementation } \\
\text { group }(n=248)\end{array}$ \\
\hline \multicolumn{2}{|c|}{ Mean age (years) (SD) } & $26 \cdot 1(4 \cdot 7)$ & $26 \cdot 5(4 \cdot 7)$ \\
\hline \multirow{2}{*}{\multicolumn{4}{|c|}{$\begin{array}{l}\text { Mean height }(\mathrm{cm})(\mathrm{SD}) \\
\text { Social class (partner's occupation): }\end{array}$}} \\
\hline & & & \\
\hline \multicolumn{2}{|l|}{ I and II } & $56 / 204(27)$ & $66 / 199(33)$ \\
\hline \multirow{2}{*}{\multicolumn{2}{|c|}{$\begin{array}{l}\text { III } \\
\text { IV and } V\end{array}$}} & $88 / 204(43)$ & $84 / 199(42)$ \\
\hline \multirow{2}{*}{\multicolumn{2}{|c|}{$\begin{array}{l}\text { IV and V } \\
\text { Student }\end{array}$}} & $51 / 204(25)$ & $49 / 199(25)$ \\
\hline & & $9 / 204(4)$ & $0 / 199$ \\
\hline \multicolumn{2}{|c|}{$\begin{array}{l}\text { Student } \\
\text { Partner unemployed }\end{array}$} & $17 / 200(9)$ & $13 / 222(6)$ \\
\hline \multicolumn{4}{|c|}{ Marital state: } \\
\hline \multicolumn{2}{|l|}{ Married } & $198 / 246(80)$ & $212 / 248(85)$ \\
\hline \multicolumn{2}{|l|}{ Single } & $33 / 246(13)$ & $24 / 248(10)$ \\
\hline \multicolumn{2}{|l|}{ Other } & $15 / 246(6)$ & $12 / 248(5)$ \\
\hline \multicolumn{2}{|c|}{ In employment } & $124 / 243(51)$ & $120 / 247(49)$ \\
\hline \multicolumn{2}{|c|}{ European } & $238 / 246(97)$ & $242 / 248(98)$ \\
\hline \multicolumn{2}{|l|}{ Primipara } & $132 / 246(54)$ & $115 / 248(46)$ \\
\hline \multicolumn{2}{|c|}{ Previous miscarriage } & $46 / 246(19)$ & $48 / 248(19)$ \\
\hline \multicolumn{2}{|c|}{ Previous terminations } & $40 / 246(16)$ & $36 / 248(15)$ \\
\hline \multicolumn{4}{|c|}{ Multiparas only: } \\
\hline \multicolumn{4}{|c|}{ Previous low birthweight } \\
\hline \multicolumn{2}{|c|}{ Previous preterm infant } & $13 / 114(11)$ & $11 / 133(8)$ \\
\hline \multicolumn{2}{|c|}{$\begin{array}{l}\text { Previous infant with growth } \\
\text { retardation }\end{array}$} & $11 / 114(10)$ & $14 / 133(11)$ \\
\hline \multicolumn{2}{|c|}{ History of nausea or vomiting } & $141 / 246(57)$ & $128 / 248(52)$ \\
\hline \multicolumn{2}{|c|}{ Current smoker } & $57 / 249(23)$ & $67 / 248(27)$ \\
\hline \multicolumn{4}{|c|}{ Blood pressure $(\mathrm{mm} \mathrm{Hg})$ : } \\
\hline Systolic & $\left\{\begin{array}{l}<110 \\
110-129 \\
\geqslant 130\end{array}\right.$ & $\begin{array}{r}59 / 246(24) \\
145 / 246(59) \\
42 / 246(17)\end{array}$ & $\begin{array}{r}54 / 247(22) \\
154 / 247(62) \\
39 / 247(16)\end{array}$ \\
\hline Diastolic & $\left\{\begin{array}{c}<60 \\
60-79 \\
\geqslant 80\end{array}\right.$ & $\begin{array}{c}15 / 246(6) \\
199 / 246(81) \\
32 / 246(13)\end{array}$ & $\begin{array}{c}19 / 247(8) \\
193 / 247(78) \\
35 / 247(14)\end{array}$ \\
\hline \multicolumn{2}{|l|}{ Proteinuria } & $10 / 246(4)$ & $19 / 247(8)$ \\
\hline \multirow{2}{*}{\multicolumn{2}{|c|}{ Urinary infection }} & $4 / 246(2)$ & $3 / 244(1)$ \\
\hline & $10 \mu \mathrm{g} / \mathrm{l}$ & $32 / 234(14)$ & $41 / 232(18)$ \\
\hline Haemoglobir & $10 \mathrm{~g} / \mathrm{l}$ & $8 / 241(3)$ & $11 / 237(5)$ \\
\hline Body weight & & & \\
\hline$<55$ & & $47 / 246(19)$ & $47 / 247(19)$ \\
\hline $55-74$ & & $171 / 246(70)$ & $166 / 247(67)$ \\
\hline$\geqslant 75$ & & $28 / 246(11)$ & $34 / 247(14)$ \\
\hline $\begin{array}{l}\text { Median zinc } \\
\text { leucocytes }\end{array}$ & $\begin{array}{l}\text { entrations in } \\
\mathrm{o} / / 10^{\prime \prime} \text { cells) }\end{array}$ & 1.192 & $1 \cdot 147$ \\
\hline
\end{tabular}

No difference was statistically significant.

TABLE II-Maternal characteristics at 28-32 weeks visit in the two groups

\begin{tabular}{|c|c|c|}
\hline & $\begin{array}{c}\text { Zinc } \\
\text { supplementation } \\
\text { group }(n=238)\end{array}$ & $\begin{array}{c}\text { Placebo } \\
\text { supplementation } \\
\text { group }(\mathbf{n}=232)\end{array}$ \\
\hline Mean weight $(\mathrm{kg})(\mathrm{SD})$ & $71 \cdot 3(10 \cdot 8)$ & $70.8(10 \cdot 7)$ \\
\hline $\begin{array}{l}\text { Mean weight gain from time of } \\
\text { booking }(\mathrm{kg}) \text { (SD) }\end{array}$ & $8.35(3.09)$ & $8 \cdot 11(2 \cdot 89)$ \\
\hline Median haemoglobin $(\mathrm{g} / \mathrm{l})$ & 117 & 115 \\
\hline \multicolumn{3}{|c|}{ Mean blood pressure $(\mathrm{mm} \mathrm{Hg})(\mathrm{SD})$ : } \\
\hline Systolic & $115 \cdot 2 \quad(12)$ & $115 \cdot 5 \quad(12)$ \\
\hline Diastolic & $68.9(9)$ & $69 \cdot 9(9)$ \\
\hline No $(\%)$ with proteinuria & $17 / 222(8)$ & $11 / 222(5)$ \\
\hline $\begin{array}{l}\text { Median zinc concentration in } \\
\text { leucocytes }\left(\mu \mathrm{mol} / 10^{11} \text { cells }\right)\end{array}$ & $0.927(\mathrm{n}=220)$ & $0.973(\mathrm{n}=224)$ \\
\hline
\end{tabular}


Compliance did not vary significantly between the two groups. At 28-32 weeks just over half claimed to be taking the supplement every day, and approaching two thirds were doing so by the time of delivery.

\section{OUTCOME MEASURES}

Complications of pregnancy-There were no significant differences in complications of pregnancy between the two groups. The mothers given zinc supplementation had similar weights, weight gains, and blood pressures, but there was a suggestion of more proteinuric hypertension in this group (11/241 mothers) than in the controls $(3 / 238)(p=0 \cdot 06)$. The incidence of proteinuric hypertension in the Bristol area is of the order of $3-4 \%$. Hence the rate among the mothers receiving zinc $(4.6 \%)$ was that expected, whereas that among the controls $(1 \cdot 3 \%)$ was less than expected.

Labour and delivery-There was no difference between the groups in any aspect of labour or delivery (table IV). In particular, mothers receiving zinc supplements were not less likely to deliver before term or to have premature rupture of the membranes, abnormal labour, postpartum haemorrhage, or postpartum infection.

Fetuses and neonates-Two twin pregnancies occurred in the zinc treated group and one in the

TABLE III-Median daily dietary intakes at 28-32 weeks in the two groups

\begin{tabular}{lcc}
\hline & $\begin{array}{c}\text { Zinc } \\
\text { supplementation } \\
\text { group }(\mathrm{n}=192)\end{array}$ & $\begin{array}{c}\text { Placebo } \\
\text { supplementation } \\
\text { group }(\mathrm{n}=183)\end{array}$ \\
\hline Energy (MJ) & $8 \cdot 5$ & $8 \cdot 3$ \\
Sugar (g) & $80 \cdot 9$ & $81 \cdot 8$ \\
Total fibre (g) & $18 \cdot 3$ & $18 \cdot 0$ \\
Cereal fibre (g) & $7 \cdot 9$ & $8 \cdot 2$ \\
Alcohol (g) & $0 \cdot 54$ & $0 \cdot 73$ \\
Protein (g) & $72 \cdot 9$ & $71 \cdot 8$ \\
Fat (g) & $91 \cdot 3$ & $89 \cdot 7$ \\
Sodium (mg) & 2662 & 2578 \\
Potassium (mg) & 3102 & 3173 \\
Calcium (mg) & 1095 & 1122 \\
Magnesium (mg) & $307 \cdot 0$ & $315 \cdot 2$ \\
Iron (mg) & $11 \cdot 4$ & $11 \cdot 5$ \\
Copper (mg) & $1 \cdot 44$ & $1 \cdot 42$ \\
Zinc (mg) & $9 \cdot 09$ & $9 \cdot 24$ \\
Vitamin C (mg) & $63 \cdot 1$ & $62 \cdot 0$ \\
Free folic acid & $70 \cdot 1$ & $68 \cdot 7$ \\
Milk (g) & $332 \cdot 1$ & $338 \cdot 4$ \\
\hline Nodifference was & & \\
\hline
\end{tabular}

No difference was statistically significant.

TABLE IV-Details of labour and delivery in the two groups. Except where stated otherwise figures are numbers (percentages) of mothers

\begin{tabular}{|c|c|c|}
\hline & $\begin{array}{l}\text { Zinc } \\
\text { supplementation } \\
\text { group }\end{array}$ & $\begin{array}{l}\text { Placebo } \\
\text { supplementation } \\
\text { group }\end{array}$ \\
\hline \multicolumn{3}{|l|}{ Gestation (weeks): } \\
\hline$<37$ & $10 / 243(4)$ & $17 / 243(7)$ \\
\hline $37-41$ & $205 / 243(84)$ & $198 / 243(81)$ \\
\hline$\geqslant 42$ & $28 / 243(12)$ & $28 / 243(12)$ \\
\hline \multicolumn{3}{|l|}{ Median zinc concentration in } \\
\hline $\begin{array}{l}\text { Onset of labour induced/ } \\
\text { emergency caesarean section }\end{array}$ & $73 / 245(30)$ & $75 / 244(31)$ \\
\hline \multicolumn{3}{|l|}{ Membrane rupture: } \\
\hline Premature rupture & $55 / 242(23)$ & $59 / 243(24)$ \\
\hline Artificial, before labour & $5 / 242(2)$ & $1 / 243(0)$ \\
\hline Other & $182 / 242(75)$ & $183 / 243(75)$ \\
\hline \multicolumn{3}{|l|}{ Presentation: } \\
\hline Vertex & $227 / 244(93)$ & $230 / 243(95)$ \\
\hline Breech & $15 / 244(6)$ & $12 / 243(5)$ \\
\hline Other & $2 / 244(1)$ & $1 / 243(0)$ \\
\hline \multicolumn{3}{|c|}{ Mean blood pressure in labour $(\mathrm{mm} \mathrm{Hg})(\mathrm{SD})$ : } \\
\hline Systolic & $124 \cdot 0(12)$ & $124 \cdot 0(12)$ \\
\hline Diastolic & $76 \cdot 9(9)$ & $76 \cdot 6(9)$ \\
\hline \multicolumn{3}{|l|}{ Method of delivery: } \\
\hline Caesarean section & $24 / 244(10)$ & $32 / 243(13)$ \\
\hline Forceps & $30 / 244(12)$ & $31 / 243(13)$ \\
\hline Spontaneous & $189 / 244(77)$ & $177 / 243(73)$ \\
\hline Other & $1 / 244(0)$ & $3 / 243(1)$ \\
\hline \multicolumn{3}{|l|}{ Median duration of labour } \\
\hline Postpartum haemorrhage & $26 / 244(11)$ & $16 / 243(7)$ \\
\hline Postpartum infection & $10 / 244(4)$ & $9 / 242(4)$ \\
\hline
\end{tabular}

No difference was statistically significant.
TABLE $v$-Details of fetuses and neonates in the two groups. Except where stated otherwise figures are numbers (percentages) of fetuses/neonates

\begin{tabular}{|c|c|c|c|}
\hline & & $\begin{array}{c}\text { Zinc } \\
\text { supplementation } \\
\text { group } \\
\left(\mathbf{n}=248^{\star}\right)\end{array}$ & $\begin{array}{c}\text { Placebo } \\
\text { supplementation } \\
\text { group } \\
\left(\mathrm{n}=249^{\star}\right)\end{array}$ \\
\hline \multicolumn{4}{|l|}{ Sex: } \\
\hline \multicolumn{2}{|l|}{ Mali } & $118 / 247(48)$ & $116 / 245(47)$ \\
\hline \multirow{2}{*}{\multicolumn{2}{|c|}{$\begin{array}{l}\text { Female } \\
\text { Birth weight }(\mathrm{g} \text { : }\end{array}$}} & $129 / 247(52)$ & $129 / 245(53)$ \\
\hline & & & \\
\hline \multicolumn{2}{|c|}{ Median } & $3390(n=247)$ & $3370(n=244)$ \\
\hline \multicolumn{2}{|l|}{ Mean $(S D)$} & $3291(581)$ & $3319(531)$ \\
\hline \multicolumn{2}{|l|}{$<2500$} & $15 / 247(6)$ & $13 / 244(5)$ \\
\hline \multicolumn{2}{|c|}{$2500-3499$} & $140 / 247(57)$ & $135 / 244(55)$ \\
\hline \multicolumn{2}{|l|}{$\geqslant 3500$} & $92 / 247(37)$ & $96 / 244(39)$ \\
\hline \multicolumn{2}{|c|}{$\begin{array}{l}\text { Mean head circumference } \\
(\mathrm{cm} \text { SD }\end{array}$} & $34 \cdot 5 \quad(1 \cdot 6) \quad(n=243)$ & $34.5 \quad(1.6) \quad(\mathrm{n}=243$ \\
\hline \multicolumn{2}{|c|}{ Mean crown-heel length } & $51 \cdot 3 \quad(4.7) \quad(n=244)$ & $51.5 \quad(4.7) \quad(n=242$ \\
\hline \multicolumn{2}{|c|}{$\begin{array}{l}(\mathrm{cm})(\mathrm{SD}) \\
\text { Mean ponderal index (weight/ } \\
\text { length })(\mathrm{SD})\end{array}$} & $2.44(0.31)(n=244)$ & $2.42(0.31)(\mathrm{n}=242$ \\
\hline \multicolumn{2}{|c|}{ Congenital defects } & $5 / 248(2)$ & $8 / 249(3)$ \\
\hline \multicolumn{2}{|c|}{ Other abnormalities } & $34 / 248(14)$ & $47 / 249(19)$ \\
\hline \multirow{2}{*}{$\begin{array}{l}\text { Apgar scores } \\
1 \text { minute }\end{array}$} & & & \\
\hline & $\left\{\begin{array}{l}<6 \\
\{\geqslant 6\end{array}\right.$ & $\begin{array}{c}16 / 244(7) \\
228 / 244(93)\end{array}$ & $\begin{array}{c}22 / 243(9) \\
221 / 243(91)\end{array}$ \\
\hline 5 minutes & $\left\{\begin{array}{l}<8 \\
\mid \geqslant 8\end{array}\right.$ & $\begin{array}{c}7 / 243(3) \\
236 / 243(97)\end{array}$ & $\begin{array}{c}8 / 243(3) \\
235 / 243(97)\end{array}$ \\
\hline \multicolumn{4}{|l|}{ Outcome: } \\
\hline \multicolumn{2}{|l|}{ Stillbir } & $3 / 248(1)$ & $3 / 249(1)$ \\
\hline \multicolumn{2}{|l|}{ Alive } & $244 / 248(98)$ & $241 / 249(97)$ \\
\hline \multicolumn{2}{|c|}{ Terminated/miscarried } & $1 / 248(0)$ & $5 / 249(2)$ \\
\hline \multicolumn{2}{|c|}{$\begin{array}{l}\text { Median zinc concentrations in } \\
\text { cord blood }\left(\mu \mathrm{mol} / 10^{10} \text { cells }\right)\end{array}$} & $1 \cdot 36(\mathrm{n}=131)$ & $1 \cdot 38(n=116)$ \\
\hline
\end{tabular}

* Two twin pregnancies occurred in the rinc supplementation group and one in the controls.

No difference was statistically significant.

control group. There were no differences in outcome between the groups (table V). In particular there was no evidence of a lower incidence of growth retardation or neonatal abnormalities in the zinc treated group. The condition of the infant at birth was identical in the two groups. There were three perinatal deaths in each group. In all, however, six pregnancies had either been terminated or ended in spontaneous abortion during the study, but the difference in distribution between the groups (one case in the zinc treated group, five cases in the control group) did not approach significance.

\section{COMPLIANCE}

The same measures of outcome were compared among compliers only. As in the whole series there were no differences at all. Similarly there was no significant difference between compliers and noncompliers apart from a significantly lower risk of postpartum infection among the compliers. When the compliers were compared with non-compliers within each supplementation group there was nothing of note.

\section{Discussion}

Given the extensive role of zinc in many enzymes and the well documented adverse effects of zinc deficiency in pregnant animals, its role in human pregnancy would also be expected to be wide. This study therefore examined a large number of clinically relevant variables.

The recommended daily intake of zinc during pregnancy is $20 \mathrm{mg}$, yet our patients were consuming less than half this. Hence we expected that supplementing with $20 \mathrm{mg}$ a day might have beneficial consequences for a large proportion of mothers. Despite monitoring many different outcomes, however, we found no detectable beneficial effects of zinc supplements.

There have been few trials of zinc supplementation in pregnancy. In a study of flawed design Kynast and Saling found that among a group receiving supplements compared with a random set of deliveries 
there was an increased incidence of large for dates and small for dates infants, preterm labour, and premature separation of the placenta. ${ }^{26}$ Their study, however, was not controlled satisfactorily and the results should be interpreted with caution. In a randomised double blind trial of zinc supplementation during pregnancy in low income Mexican women Hunt et al found a significantly lower risk of pregnancy induced hypertension in the supplemented group. ${ }^{27}$ There was no difference between the two groups with regard to other indicators of abnormal outcome of pregnancy, such as infections, premature rupture of the membranes, preterm delivery, post-term pregnancy, bleeding during labour, or infant outcome.

Our study, though the largest to date, had certain weaknesses which may have contributed to the failure to show any significant differences. The women recruited were mainly a middle class population from the south west of England, and they were of at least adequate nutritional state despite their low zinc intake. They may therefore have had sufficient zinc stores and did not need supplemental zinc. This is supported by their mean leucocyte zinc concentrations, which were not increased by zinc supplementation. Nevertheless, the maternal serum zinc concentrations that we recorded were higher than that used by Simmer and Thompson as the cut off point to predict women likely to deliver a small for dates infant $(0 \cdot 92) .^{23}$

The other explanation possibly lies in the size of the study population, and in particular the size of the population with low zinc state. Our calculations of sample size required had used data from a similar study population in Bristol, which indicated that there would be a $50 \%$ reduction in risk with adequate zinc. If we assume an incidence of intrauterine growth retardation to be about $10 \%$, then to detect a $25 \%$ decrease at the $5 \%$ level of significance with a $90 \%$ degree of confidence we should have to study a sample of 2600 women in each group. Nevertheless, to show a difference in mean birth weight of $100 \mathrm{~g}$ would require a sample size of only 700 in each group.

This is the largest study to date assessing the effect of zinc supplementation during pregnancy. The results failed to show any relation between zinc supplementation and an improved outcome of pregnancy. On the basis of present evidence we argue against any recommendation for routine zinc supplementation to all pregnant women. We think that future trials of zinc supplementation should be concentrated on selected groups of women with poor dietary intake and at high risk of complications during pregnancy.

We are grateful to Smith Kline and French, who supplied the zinc and placebo tablets and contributed to the funding of the study; Mr Gary Tanner, who helped with the computer analysis; Mr Terry Shenton, who set up the files; Mrs Mary Pears, who coded the dietary data; Kelly Harvey and Fiona Braddon, who provided dietary advice; and Yasmin Iles for typing the many versions of this manuscript.

\section{Appendix}

OUTCOME MEASURES CONSIDERED

(1) Maternal infections:

(a) Any infection during pregnancy requiring a visit to the doctor

(b) Puerperal sepsis (fever over $37 \cdot 6^{\circ} \mathrm{C}$ associated with lower abdominal pain and abnormal lochia occurring within six weeks after delivery)

(2) Maternal bleeding:

(a) Bleeding in first trimester

(b) Unspecified antepartum haemorrhage

(c) Placental abruption (antepartum haemorrhage) associated with abdominal pain and tenderness

(d) Placenta praevia.
(3) Hypertension (diastolic pressure $90 \mathrm{~mm} \mathrm{Hg}$ or more on two separate occasions more than six hours apart):

(a) Any hypertension

(b) Proteinuric hypertension (more than trace on two consecutive occasions four to six hours apart on dipstick testing).

(4) Period of gestation:

(a) Mean gestational age (calculated in days from the first day of the last menstrual period or on the basis of an ultrasound scan in the first half of pregnancy if the date of the last menstrual period was thought to be inaccurate)

(b) Preterm labour - that is, labour resulting in delivery before 37 completed weeks

(c) Post dates-that is, delivery after 41 completed weeks.

(5) Labour:

(a) Spontaneous onset

(b) Premature rupture of membranes (rupture of membrane without onset of regular uterine contractions within 12 hours)

(c) Duration of labour

(d) Atonic postpartum haemorrhage

(e) Mode of delivery.

(6) Fetal size:

(a) Birth weight

(b) Birth weight less than 10th centile (for sex and gestation)

(c) Head circumference

(d) Crown-heel length.

(7) Apgar scores at 1 and 5 minutes.

(8) Congenital malformations - that is, any noted.

(9) Other abnormalities or problems in the neonatal period.

(10) Outcome:

Stillbirth or neonatal death.

1 Dusanaka MD. Methodology of zinc determinants and the role of zinc in biochemical processes. Adv Clin Chem 1970;13:271

2 Apgar $J$. Effect of zine deficiency in maintenance of pregnancy in the rat. $\mathcal{J}$ Nutr 1970;100:470.

3 McKenzie JM, Forsmire CJ. Zinc deficiency during the latter third of pregnancy: effect on fetal rat brain, liver and placenta. I Nutr 1975;105: $1+66-73$

+ Verburg DI, Burd LJ, Hoxtill EO, Merrill LK. Acrodermatitis enteropathica and pregnancy. Obstet Gynecol 1974;593:233.

5 Jameson S. Effects of zinc deficiency in human reproduction. Actu Med Scand 1976;593:3-89

6 Kuilholma P, Gronroos M. Erkkola P, et al. The role of calcium, iron, copper and zinc in preterm delivery and premature rupture of membranes. Gynecol and zinc in preterm delivery and

7 Kuilholma $P$, Erkkola P, Pakarinen $P$, et al. Trace metals in post date pregnancy. Gynecol Obstet Invest 1984;18:45-8.

Metcoff J, Constiloc JP. Crosby W, al. Maternal nutrition and fetal outcome. Am $\mathcal{F}$ Clin Nutr 1981;34:708-21.

9 Cherry FF, Bennett EA, Bazzano GS, et al. Plasma zinc in hypertension toxemia and other reproductive variables in adolescent pregnancy. A $m \mathcal{F}$ Clin Nutr 1981;34:2367-75.

10 Prema K. Predictive value of serum copper and zinc in normal and abnormal pregnancy. Indian f Med Res 1980;71:554-60.

11 Ghosh A, Fong LYY, Wan CW, et al. Zinc deficiency is not a cause of abortion, congenital abnormality and small-for-gestational age infants in Chinese women. Br f Obstet Gynaecol 1985;92:886-91.

12 Prasad LSN, Ganguly SK, Vasuki K. Role of zinc in fetal nutrition. Indian Pediatr 1974;11:799-802.

13 Atinmo T, Mbofung C, Osinusi BO. Relationship between zinc and copper concentration in maternal and cord blood and birth weight. Int $\mathcal{f}$ Gynaecol Obstet 1980;18:452-4.

It McMichael AJ, Droesti IE, Gibson GT, et al. A prospective study of serial maternal serum zinc levels and pregnancy outcome. Early Hum Dev 1982;7:59-69.

15 Tuttle S, Aggett PJ, Campbell D, et al. Zinc and copper nutrition in human pregnancy: a longitudinal study in normal primigravida and in primigravida at risk of delivering a growth retarded baby. Am J Clin Nutr 1985;41: 1032 41 .

16 Meadows NJ, Ruse W, Smith MF, et al. Zinc and small babies. Lancet $1981 ;$ ii: $1135-7$

17 Mukheriee MD, Sandstead HH, Ratnaparkhi MV, et al. Maternal zinc, iron folic acid and protein nutriture and outcome of human pregnancy. $\mathrm{Am} \mathcal{J}$ Clin Nutr 1984;40:496-507.

18 Solomons NW. On the assessment of zinc and copper nutriture in man. Am $\mathcal{F}$ Clin Nutr 1979;32:856-71.

19 Jones RB, Keeling PWN, Hilton PJ, et al. The relationship between lencocvte and muscle zinc in health and disease. Clin Sci 1981;60:237-9.

20 Keeling PWN, Jones RB, Hitton PJ, Thompson RPH. Reduced leucocyte zinc in liver disease. Gut 1980;21:561-4.

21 Meadows N. Ruse W, Keeling PWN, et al. Peripheral blood leucocyte zinc 

1983:58:807-9

22 W'ells JL, James DK, Luxton R, Pennock CA. Maternal leucocite zinc deficiency at start of third trimester as a predictor of fetal growth retardation. Br.11ed f 1987:294:1054-6.

3 Simmer K, Thompson RPH. Maternal zinc and intrauterine growth retardation Clin Si 1 1985:68:395-9.

24 Paul AA, Southgate DAT, eds. McCance and Widdowson's the composition of

foods. th ed. London: HMSO, 1985. (MRC special report No 297 .)

25 Braddon FEM, Wadsworth MEJ, Davies JMC, Cripps HA Social and regional differences in food and alcohol consumption and their measurement in a national birth cohort. F Epidemiol Communtty Health 1988:42:341-9. ynast G, Saling E. Effect of oral zinc application during pregnancy. (jvinecol Obstet Invest 1986;21:117-23.

27 Hunt IF, Murphy NJ, Cleaver AE, et al. Zinc supplementation during pregnancy: effects on selected blood constituents and on progress and outcome of pregnancy in low income women of Mexican descent. Am $7 \mathrm{Clin}$ Nutr 1984:40.508-21.

\title{
Failure of interferon alfa and tribavirin in rabies encephalitis
}

\author{
M J Warrell, N J White, Sornchai Looareesuwan, R E Phillips, Pravan Suntharasamai, \\ Pornthep Chanthavanich, Mario Riganti, S P Fisher-Hoch, K G Nicholson, Sathaporn Manatsathit, \\ Suparp Vannaphan, D A Warrell
}

Hospital for Tropical Diseases, Faculty of Tropical Medicine, Mahidol University Bangkok, Thailand M J Warrell, MRCPATH, consultant

N J White, FRCP, Wellcome tropical lecturer

Sornchai Looareesuwan, $\mathrm{MD}$, associate professor R E Phillips, FRACP, Wellcome tropical lecturer Pravan Suntharasamai, MD, associate professor

Pornthep Chanthavanich, $\mathrm{MD}$, associate professor Mario Riganti, MD, associate professor of pathology Suparp Vannaphan, BN, head nurse

D A Warrell, FRCP, consultant

Special Pathogens

Laboratory, Centre for

Applied Microbiology and

Research, Public Health

Laboratory Service, Porton

Down, Wiltshire

$S$ P Fisher-Hoch, MD,

Wellcome research fellow

Division of Communicable Diseases, Medical

Research Council, Clinical

Research Centre, Harrow, Middlesex

K G Nicholson, MD, scientific staff

Bamrasnaradura Hospital, Nontaburi, Bangkok,

Thailand

Sathaporn Manatsathit, MRCP, consultant

Correspondence to: Dr.M J Warrell,

John Radcliffe Hospital, Headington, Oxford OX3 9I)U

Br.Med f 1989;299:830-3
Abstract

Objective-To test the effect of interferon alfa and tribavirin (ribavirin) in patients with rabies encephalitis.

Design-An open trial of chemotherapy and intensive care in patients with early rabies.

Setting-The intensive care unit of a Bangkok hospital.

Patients-Four conscious men with clinical rabies encephalitis.

Interventions-Rapid virological diagnosis of rabies. Treatment with intravenous and intraventricular injections of high doses of lymphoblastoid interferon alfa in three patients and tribavirin in one patient. Intensive care was given throughout.

Main outcome measures-Rabies infection confirmed by antigen detection and virus isolation. Rabies neutralising antibody and specific IgM sought in serum and cerebrospinal fluid. Interferon concentrations monitored before and during treatment in three patients.

Results - Interferon alfa treatment produced high concentrations in serum and cerebrospinal fluid. All four patients died after $51 / 2$ to $12 \frac{1}{2}$ days of treatment with no evidence of virostatic or clinically beneficial effects from either treatment.

Conclusion-Interferon alfa treatment is not effective in rabies encephalitis. The use of tribavirin warrants further study, possibly combined with new therapeutic methods.

\section{Introduction}

No records exist of patients surviving furious rabies encephalitis. The three reports of recovery from rabies followed predominantly paralytic illnesses. ${ }^{1-4}$ The diagnosis rested on high concentrations of antibody to the rabies virus in serum and cerebrospinal fluid, but no rabies virus or antigen was detected. Further attempts at intensive care have failed to save patients with rabies. ${ }^{512}$ Clearly, additional therapeutic approaches are necessary.

Interferon prevents replication of the rabies virus in vitro, ${ }^{13-15}$ and a single dose of an interferon inducer given 24 hours after inoculation of the virus protects rabbits against rabies. ${ }^{16}$ Treatment with interferon from human leucocytes affords protection of infected monkeys even if given 11 days after rabies inoculation. Furthermore, interferon treatment has been most effective when given by combined intramuscular and intralumbar routes in monkeys. ${ }^{1-}$ Although endogenous interferon has been detected in some humans with rabies, the concentrations were very low, even in brain tissue sampled at necropsy. ${ }^{18}$ Treatmen with exogenous interferon has been ineffective if used late in the illness ${ }^{1819}$ so we treated patients with early rabies encephalitis with high doses of interferon alfa.

Tribavirin, which selectively blocks the synthesis of viral guanosine nucleotides, is effective against rabies virus, in vitro. ${ }^{2021}$ Protection of mice from rabies by tribavirin treatment has been attempted. A short course of daily injections was given either intramuscularly early or intracerebrally late in the incubation period.". Mortality was not affected, but such brief treatment does not exclude benefit from continuous high concentrations of tribavirin in serum and cerebrospinal fluid. Animal experiments with tribavirin to treat other intracranial viral infections indicate that it does not cross the blood-brain barrier rapidly. ${ }^{23+4}$ This has been confirmed by pharmacokinetic experiments in monkeys (M Ussery, personal communication), though it has been found in the cerebrospinal fluid of patients with AIDS after several weeks of oral treatment. ${ }^{25}$ High doses of intravenous tribavirin have proved effective in Lassa fever in humans..$^{26}$ Tribavirin has not been used intrathecally, but toxicity studies in monkeys showed that five daily injections of $2 \mathrm{mg} / \mathrm{kg}$ by the lumbar route was safe ( $G$ Ward, unpublished findings). We therefore also investigated the use of tribavirin in rabies encephalitis.

We carried out an open trial of combined intravenous and intrathecal interferon or tribavirin in four fully conscious, cooperative patients with early rabies encephalitis.

\section{Patients and methods}

All patients were admitted to Bamrasnaradura Hospital, Bangkok, and subsequently transferred to the intensive care isolation unit of the Hospital for Tropical Diseases, Bangkok, when the diagnosis of rabies was strongly suspected on the basis of the history and clinical signs. Patients were transferred only with their own fully informed consent and that of their accompanying family. The study was approved by the ethical committees of the Faculty of Tropical Medicine, Mahidol University, and the Thai Ministry of Public Health.

Except in one patient with clinically obvious rabies the diagnosis was confirmed before treatment by detection of rabies antigen around the hair follicles from a skin biopsy specimen with an immunofluorescence test."

When the patients arrived blood and cerebrospinal fluid samples were taken from baseline biochemical, haematological, viral, and drug assays. We inserted an Ommaya reservoir into a lateral cerebral ventricle and a tracheostomy tube under general anaesthesia. A temporary pacemaker was introduced under local 